\title{
Ozone variation during a case of cyclogenesis
}

\author{
H. Abdel BASSET ${ }^{1 *}, \mathrm{~A} . \mathrm{BADAWY}^{2}$ and M. EID ${ }^{1}$ \\ ${ }^{1}$ Department of Astronomy and Meteorology, Faculty of Science, Al-Azhar University, Cairo, Egypt. \\ ${ }^{2}$ Egyptian Meteorological Authority, Cairo, Egypt. \\ *Corresponding author; email: heshmatm@yahoo.com
}

Received: September 10, 2018; accepted: September 13, 2019

\begin{abstract}
RESUMEN
Se estudió la relación entre el ozono total en columna (TCO, por sus siglas en inglés) y el desarrollo de un sistema ciclónico que se presentó entre el 18 y el 25 de enero de 1981, utilizando para ello la base de datos del reanálisis ERA-Interim. Se encontró que el TCO aumenta y disminuye con el desarrollo y debilitamiento del sistema ciclónico. También se encontró una buena correlación entre el TCO y el grosor de la capa de 1000 a $100 \mathrm{hPa}$ y la presión de la tropopausa. El estudio de las variaciones diarias del TCO con base en la distribución vertical de la razón de mezcla de la masa de ozono (OMR, por sus siglas en inglés) demuestra que al inicio del periodo de crecimiento hay una importante disminución en la altura de la tropopausa asociada con la intensificación del ciclón y acompañada de un aumento vertical significativo de la OMR en la troposfera y la estratosfera. El aumento obviamente significativo de la OMR empieza en la capa estratosférica y después se traslada a la troposfera. El análisis de la variación en la altura de la OMR con relación al tiempo, respecto del promedio del dominio donde se ubica el centro del ciclón y el correspondiente promedio mensual, demuestran que en los días de máxima intensificación los valores positivos de la OMR se extienden hacia abajo hasta alcanzar el nivel de los $850 \mathrm{hPa}$. El incremento de los valores positivos de la OMR continúa siendo mayor en los niveles superiores y alcanza valores máximos entre 300 y $100 \mathrm{hPa}$, así como en la capa de 60-10 hPa. Las características de estos cambios en las concentraciones de la OMR entre capas se deben a procesos dinámicos, al efecto de la advección horizontal de ozono desde una región cercana hacia el interior de la columna, y al intercambio vertical de aire entre el ozono estratosférico y el troposférico.
\end{abstract}

\section{ABSTRACT}

The relationship between total column ozone (TCO) and the development of a cyclonic system that occurred in the period from January 18 to January 25, 1981 has been studied using the ERA-Interim reanalysis database. It was found that TCO increases and decreases with the development and weakening of the cyclonic system. Also, a good correlation between TCO and the thickness of the layer was found between 1000-100 hPa and tropopause pressure. The study of daily variations in TCO based on the vertical distribution of the ozone mass mixing ratio (OMR) illustrate that with the beginning of the growth period there is a high decrease of the tropopause height, which was associated to high deepening of the cyclone and was accompanied by a significant vertical increase of OMR in the troposphere and stratosphere. The obvious significant increase of OMR starts at the stratospheric layer and is then transported to the tropospheric layer. The analysis of the time-height variation of the differences of OMR between the average of the domain containing the center of the cyclone at each level and the corresponding monthly average, illustrates that during the days of maximum deepening the positive values of OMR extend downwards to reach the $850 \mathrm{hPa}$ level. The increase in positive values continues to be higher in the upper levels and reaches maximum values between $300-100 \mathrm{hPa}$ and also between the 60-10 hPa layer. The characteristics of these changes of OMR concentrations from layer to layer are predominantly due to dynamical processes. Also, this was attributed to the effect of horizontal advection of ozone from a different neighboring region into the column, and by a vertical exchange of air between the high ozone at the stratosphere and low ozone at troposphere. 
Keywords: total column ozone, cyclone, cyclogenesis, tropopause pressure, atmospheric thickness, stratosphere, troposphere, ozone mixing ratio.

\section{Introduction}

The correlation between the total amount of ozone and its meteorological characteristics has been appreciated since the beginning of research on atmospheric ozone. The earlier works of Dobson (Dobson and Harrison, 1926; Dobson et al., 1929, 1946; Dobson, 1931) deal with the connection between synoptic-scale circulation phenomena and total ozone. They show that maximum positive deviations of daily values from the monthly means are generally found to the rear of surface low-pressure areas, while maximum negative deviations are found to the rear of surface highs; also, they found that for many occlusions the maximum positive deviations occur directly over the surface low rather than to the rear. Reed (1950) pointed out that ozone variations are not only caused by chemical processes but also have dynamical origins, expressed by sudden increases in a total amount of ozone accompanying marked increases in tropopause pressure, such as found during the passage of a cold front or depression. Other studies by Reiter and Gao (1982), Uccellini et al. (1985), Shapiro et al. (1982) should also be mentioned. A close relation between potential vorticity (PV) and total ozone is pointed out by Vaughan and Price (1989). Abdel-Basset and Gahein (2003) found that a strong correlation between total column ozone (TCO) and PV remains stable on all levels and the maximum transport of ozone from the stratosphere to troposphere coincides with the maximum developing system, and also with maximum values of PV. The vertical structure of ozone distribution from ozone sounding was studied by Dobson (1973). Dütch (1978) collected ozone soundings data worldwide and presented a climatic analysis of the vertical ozone distribution on a global scale. The direct connection between stratosphere-to-troposphere transport (STT) and peaks in ground-level ozone observations are generally infrequent, with only a small fraction of STT trajectories descending below the mid-troposphere (Viezee et al., 1983; Derwent et al., 1998; Eisele et al., 1999; Stohl et al., 2001; Škerlak et al., 2014). Air from the free troposphere is largely limited to daytime entrainment into the lowest layer of the atmosphere as the planetary boundary layer (PBL) height increases (e.g., Itoh and Narazaki, 2016; Ott et al., 2016); however, the ability for ozone rich air to reach the surface depends on a complex array of factors including the diurnal cycle (Langford et al., 2009, 2012; Itoh and Narazaki, 2016; Ott et al., 2016) and the seasonal cycle of the PBL height (Langford et al., 2015, 2017). Kuang et al. (2017) revealed that the upper air ozone generally increases with increasing temperature or decreasing relative humidity $(\mathrm{RH})$, similarly to the surface. The presence of convective mixing (Thompson et al., 1994; Eisele et al., 1999; Langford et al., 2017), and the elevation of the monitoring station, which is located within the free troposphere, especially with the nighttime collapse of the PBL, can experience direct STT (Langford et al., 2015, 2017). A number of studies has been reported regarding the close link between jet streams and gradients in the total amount of ozone (Reiter and Gao 1982; Shapiro et al., 1982) and the marked signatures on total amount of ozone maps of features such as tropopause folds and cut-off-lows (Uccellini et al., 1985; WMO 1986, Vaughan and Price 1989). However, comparatively little has been understood about the extent to which horizontal variability in the total amount of ozone simply reflects variability in the pressure or structure of the tropopause and the extent to which it reflects variability near the ozone maximum.

The purpose of the present work is to study the relationship between TCO and the development of a cyclonic system that occurred over the Mediterranean area during the period January 18-25, 1981. The study continues with a description of the data used, including TCO and the meteorological reanalysis variables, in section 2 , where methodology is also explained. The synoptic situation and the role of polar and subtropical jets are discussed in section 3. The horizontal distribution of TCO and tropopause pressure is presented in section 4. The relationship between TCO and cyclogenesis is quantified in section 5. Discussion of how cyclones may influence the vertical variability of TCO is given in section 6 , with final conclusions in section 7 . 


\section{Data and methodology}

\subsection{Data}

ERA-Interim reanalysis data (Dee et al., 2011) is the latest global atmospheric reanalysis data set of the European Centre for Medium-Range Weather Forecasts (ECMWF) with a period from 1979 to 2018 with a $1^{\circ} \times 1^{\circ}$ resolution is used for obtaining the TCO and meteorological parameters (http://apps.ecmwf.int/ datasets/data/interim-full-moda). It consists of the horizontal wind components (u- eastward, v-northward), temperature (T), geopotential height ( $\mathrm{z}$ ) and ozone mass mixing ratio (OMR) for 37 isobaric levels from 1000 to $1 \mathrm{hPa}$ on regular latitude-longitude grid points with $1^{\circ} \times 1^{\circ}$ resolution. Data is available at 0000, 0600, 1200 and 1800 UTC. The extracted domain of study extended from 10.0 to $70.0^{\circ} \mathrm{N}$ and from $10.0 \mathrm{~W}$ to $70.0^{\circ} \mathrm{E}$ for the period January 18 to 25,1981 . TCO data were directly downloaded due to its units (DU) while OMR data were downloaded for 37 isobaric levels taken as meteorological parameters (the OMR unit is ppm). The inner domain used in our calculations for the present study changes with time to enclose the cyclone during its life cycle (Fig. 2). For each day, the average total amount of ozone was estimated by calculating the average gridded ozone values inside the domain (Fig. 2), which encloses the cyclone cell over the period of study (January 18 to $25,1981)$. Therefore, calculations of the total amount of ozone average and meteorological parameters were made only over this domain, to have a better view of the total amount of ozone variations with meteorological parameters.

\subsection{Vertical tilt of the wave and northward transport of heat}

In this section, we derive the conditions for the westward tilt of a wave with height using the two-level quasi-geostrophic model discussed by Holton (1972). Our problem depends on the correlation between the perturbation thickness $\left(\psi_{1}{ }^{\prime}-\psi_{3}{ }^{\prime}\right)$ and meridional velocity $\partial\left(\psi_{1}{ }^{\prime}-\psi_{3}{ }^{\prime}\right) / \partial x$ at $500 \mathrm{hPa}$. In order to understand this, it is helpful to consider a particular sinusoidal wave disturbance. Suppose that the barotropic and baroclinic parts of the disturbance can be written respectively as

$$
\begin{aligned}
& \psi_{1}^{\prime}+\psi_{3}^{\prime}=A_{M} \cos k(x-c t) \\
& \psi_{1}^{\prime}-\psi_{3}^{\prime}=A_{T} \cos k\left(x+x_{0}-c t\right)
\end{aligned}
$$

where $\psi_{1}{ }^{\prime}$ and $\psi_{3}{ }^{\prime}$ represent the perturbations of the stream functions $\psi_{1}^{\prime}$ and $\psi_{3}{ }^{\prime}$ at 250 and $750 \mathrm{hPa}$, respectively; $x_{0}$ designates the phase difference; $\psi_{1}{ }^{\prime}+\psi_{3}{ }^{\prime}$ is proportional to the $500 \mathrm{hPa}$ geopotential, and $\psi_{1}{ }^{\prime}-\psi_{3}{ }^{\prime}$ is proportional to the $500 \mathrm{hPa}$ temperature. The phase angle $k x_{0}$ gives the phase difference between the geopotential and temperature fields at $500 \mathrm{hPa}$. Furthermore, $A_{M}$ and $A_{T}$ are the measures of the amplitudes of the $500 \mathrm{hPa}$ disturbance geopotential and temperature fields, respectively. Using the expressions in Eq. (1) we obtain

$$
\begin{aligned}
& \left\langle\left(\psi_{1}^{\prime}-\psi_{3}^{\prime}\right) \frac{\partial}{\partial x}\left(\psi_{1}^{\prime}+\psi_{3}^{\prime}\right)\right\rangle= \\
& -\frac{k}{L} \int_{0}^{L} A_{T} A_{M} \cos k\left(x+x_{0}-c t\right) \sin k(x-c t) d x \\
& \quad=\frac{k A_{T} A_{M} \sin k x_{0}}{L} \int_{0}^{L}[\sin k(x-c t)]^{2} d x \\
& \quad=\frac{k A_{T} A_{M} \sin k x_{0}}{2}
\end{aligned}
$$

From Eq. (2) we can see that for the usual mid-latitude case the relationship between geopotential and temperature fields must be positive if $x_{0}$ satisfies $0<k$ $x_{0}<\pi$. Furthermore, the correlation will be a positive maximum for $k x_{0}=\pi / 2$ when the temperature wave lags the geopotential wave by $90^{\circ}$ at $500 \mathrm{hPa}$. It should also be noted here that if the temperature wave lags the geopotential wave, the trough and ridge areas will tilt westward with height, which is observed to be the case for amplifying mid-latitude synoptic systems.

\section{Synoptic discussion}

Based on the 1000 and $500 \mathrm{hPa}$ charts the life cycle of our cyclone can be divided as following: the first two days (January 18-19) immediately precede the onset of cyclogenesis and can be termed as pre-cyclogenetic period. The third, fourth and five days (January 20-22) are the growth period, and finally, the last three days (January 23-25) are the decay period. This is a typical case of mid-latitude and Mediterranean cyclogenesis (Karacostas and Flocas, 1983; Lionello et al., 2006; Homar et al., 2007; Kouroutzoglou et al., 2011, 2013z). It has long been recognized that cyclogenesis to the lee of the Alps occurs typically with cold air outbreaks crossing the massif from north or northwest and that the primary influence upon cyclogenesis is orographic (Buzzi 
and Tibaldi 1978; Gomis et al. 1990). This cyclone evolved between 1200 UTC on January 18-25, 1981, while strong cyclogenesis occurred during 1200 UTC on January 20-22, 1981 over the Mediterranean Sea. Figures 1 and 2 show the 1000 and $500 \mathrm{hPa}$ geopotential analysis for the period from January 18-12 to 25-12, respectively.

At 1200 UTC on January 19, Figures $1 b$ and 2b show that a weak low-pressure system with a surface center of 60 geopotential meters (gpm) is located south of Italy and is associated to a baroclinic upper air trough. During the next $24 \mathrm{~h}$, the center of the surface low propagates slowly to the southeastward and deepens to 40 gpm (Fig. 1c). A corresponding upper air trough formed at $500 \mathrm{hPa}$ on January 20 at 0000 UTC was shifted eastward (Fig. 2c). On January 21 at 1200 UTC, Figure 1d shows that the low pressure was deepened to -120 gpm and moved southeast to a point just north of Italy. The development of the upper air trough was accompanied by lee cyclogenesis that started on January 20 at 1200 UTC associated to a cut-off low formed at $500 \mathrm{hPa}$ over the middle of Europe with a center of $5160 \mathrm{gpm}$. Meanwhile, the Siberian high extended to include most of the northeast of Europe, and a new high-pressure developed over western Europe. On January 21 at 0000 UTC (Fig. 1e), the center of the surface pressure is located over south Italy and the north of Libya with more deepening, where the geopotential height at $1000 \mathrm{hPa}$ reaches $-100 \mathrm{gpm}$. The associated upper air trough at $500 \mathrm{hPa}$ (Fig. 2e) moved southeastward where the geopotential height at its cutoff low was $5200 \mathrm{gpm}$. Figure 2f (January 21, 1200 UTC) illustrates that the center of the cyclone moved about 15 latitudes southward during $24 \mathrm{~h}$, from $50^{\circ}$ $\mathrm{N}, 15^{\circ} \mathrm{E}$ on January 20 at $1200 \mathrm{UTC}$ to $35^{\circ} \mathrm{N}, 15^{\circ} \mathrm{E}$ on January 21 at 1200 UTC. From January 22 at 0000 UTC to January 23 at 000 UTC, the center of the cyclone moved slowly eastward with slight filling and reached 5200 gpm at $500 \mathrm{hPa}$ on on January 23 at 0000 UTC (Fig. 1i). Also, at $1000 \mathrm{hPa}$ the geopotential height at the center of the cyclone increased gradually to reach $-40 \mathrm{hPa}$ on January 23 at 0000 UTC (Fig. 1i). During the next two days (January 23-24) the depression started filling and its central pressure increased gradually. On the other hand, the high pressure over the Atlantic extended eastward with a major ridge that joined with the Siberian high on January 22 (Fig. 1h). This means that the subtropical high pressure prevented the northwest cold air (cold advection) from the south and middle of Europe from reaching the cyclone. While the Siberian high extended westward the horizontal extension of the cyclone decreased and moved slowly eastward, becoming a stationary vortex rotating above the northeastern Mediterranean. Finally, the cyclone drifted slowly northeastward and was out of the computational domain after January 25.

\subsection{Behavior of the polar and subtropical jets}

It is known that the subtropical (polar) jet has its maximum speed around $200 \mathrm{hPa}(300 \mathrm{hPa})$ (Namias and Clapp 1949; Loewe and Radok 1950; Mohri 1953; Newton 1954; Sutcliffe and Bannon 1954; Defant and Taba 1957; Krishnamurti 1961; Riehl 1962; Palmén and Newton 1969; Keyser and Shapiro 1986; Shapiro and Keyser 1990). Figure 3 displays the horizontal distribution of wind speed (in isotachs) at the $300 \mathrm{hPa}$ level to show the behavior of the polar and subtropical jets during the life cycle of the cyclone. On January 19, 1981 at 1200 UTC (Fig. 3b), the maximum speed of the subtropical jet core was $60 \mathrm{~m} \mathrm{~s}^{-1}$ and was located over North Africa (northern Libya, Egypt and the northern Red Sea). Its speed at $200 \mathrm{hPa}$ is greater than $60 \mathrm{~m} \mathrm{~s}^{-1}$ (not shown). The polar jet extended from northwest England to southeast Spain and the north of Italy with a maximum wind speed greater than $70 \mathrm{~m} \mathrm{~s}^{-1}$ at $300 \mathrm{hPa}$. Its extension at $200 \mathrm{hPa}$ has a maximum wind speed greater than $65 \mathrm{~m} \mathrm{~s}^{-1}$ (not shown). On January 20 at 0000 UTC, the subtropical jet moved slightly northeastward and its maximum center, located over Egypt, became greater than 60 $\mathrm{m} \mathrm{s}^{-1}$ at $200 \mathrm{hPa}$. On January 20 at $1200 \mathrm{UTC}$, the polar jet moved southeastward to amalgamate with the subtropical jet and its maximum value became greater than $70 \mathrm{~m} \mathrm{~s}^{-1}$ at $300 \mathrm{hPa}$. On January 21, 1981 at 1200 UTC, the subtropical jet shifted to the southeast while the front of the polar jet reached northern Algeria and the value of its maximum jet was greater than $80 \mathrm{~m} \mathrm{~s}^{-1}$ at $300 \mathrm{hPa}$. The subtropical jet weakened at $300 \mathrm{hPa}$ and became stronger at $200 \mathrm{hPa}$ $\left(>70 \mathrm{~m} \mathrm{~s}^{-1}\right)$, moving eatsward. Beginning on January 22 at 1200 UTC up to January 24 at 1200 UTC the polar jet became weak at $300 \mathrm{hPa}$ and its extension on $200 \mathrm{hPa}$ disappeared. Also, it is noticed that the subtropical jet moved eastward and almost returned to its normal distribution both in speed and direction. 

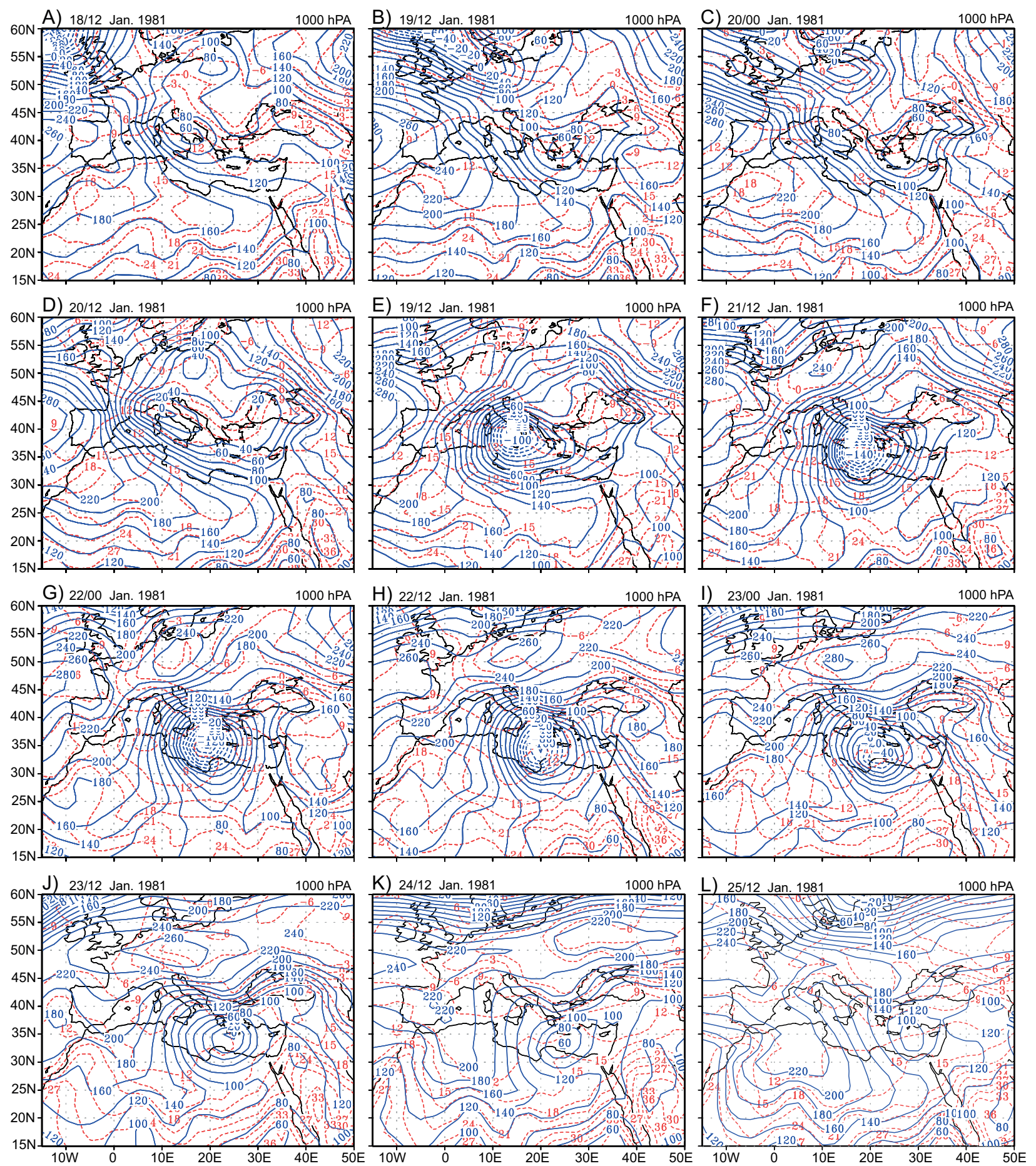

Fig. 1. $1000 \mathrm{hPa}$ height contours in $40 \mathrm{gpm}$ intervals (solid) and temperature (dotted) in $5{ }^{\circ} \mathrm{C}$ increments for $1200 \mathrm{UTC}$ on January 18-25, 1981.

\subsection{Tilting behavior}

To illustrate the behavior of the vertical axis tilt with the development of our case study (according to the theoretical analysis in subsection 2.2) we computed the perturbation temperature $T^{\prime}$ (thickness) and meridional velocity $V^{\prime}$, and then calculated the product 

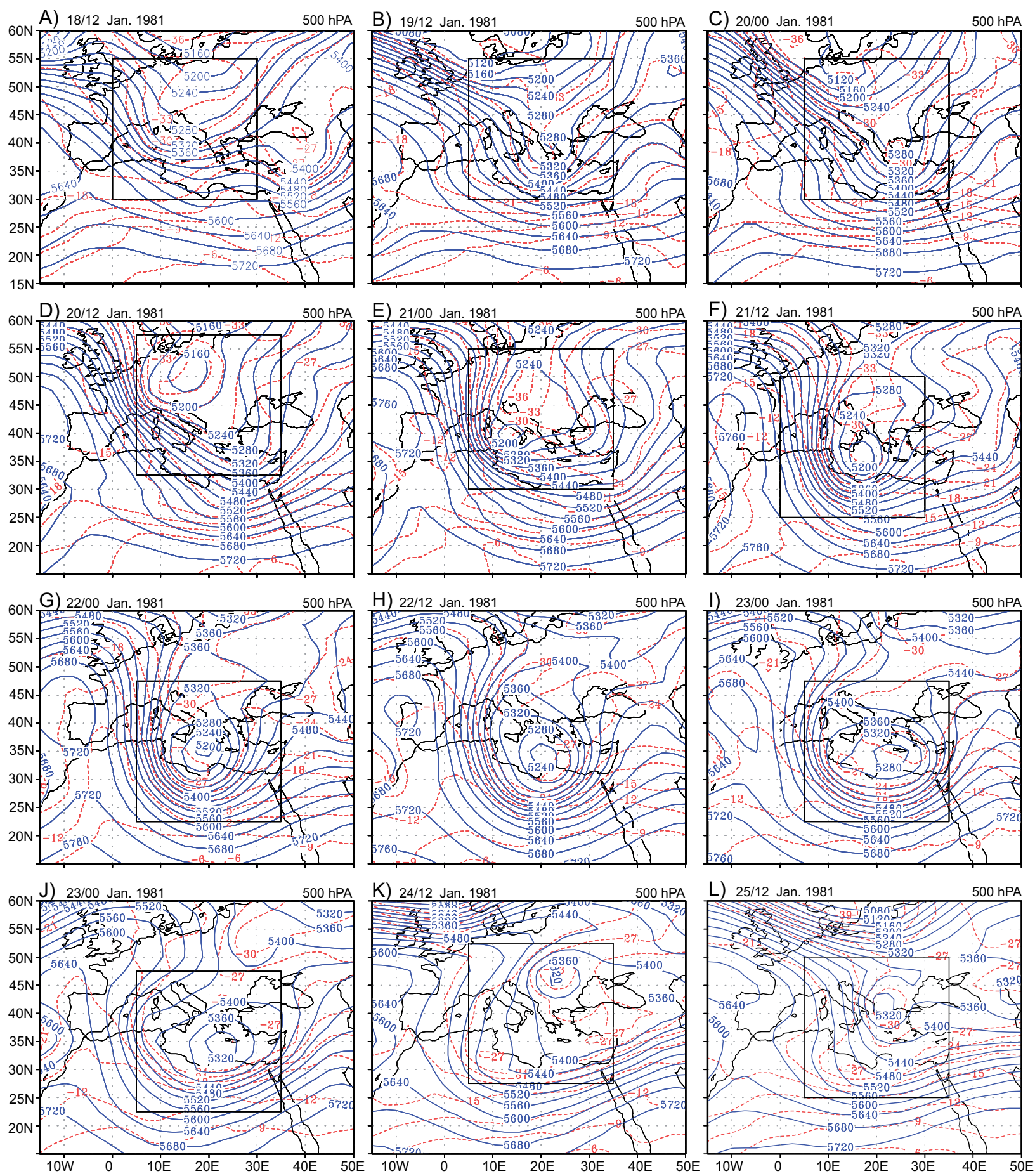

Fig. 2. $500 \mathrm{hPa}$ height contours in $60 \mathrm{gpm}$ intervals (solid) and temperature (dotted) in $5{ }^{\circ} \mathrm{C}$ increments for $0000 \mathrm{UTC}$ on January 18-25, 1981.

of these two variables over the computational domain. Fig. 4a shows the time height variation of $T^{\prime} V^{\prime}$ throughout the life cycle of the cyclone, while Fig. $4 \mathrm{~b}$ illustrates the area average integrated values of $T^{\prime} V^{\prime}$ for the period of interest. It is clear that $T^{\prime} V^{\prime}<0$ below $800 \mathrm{hPa}$ from January 18 at 1800 UTC to January 

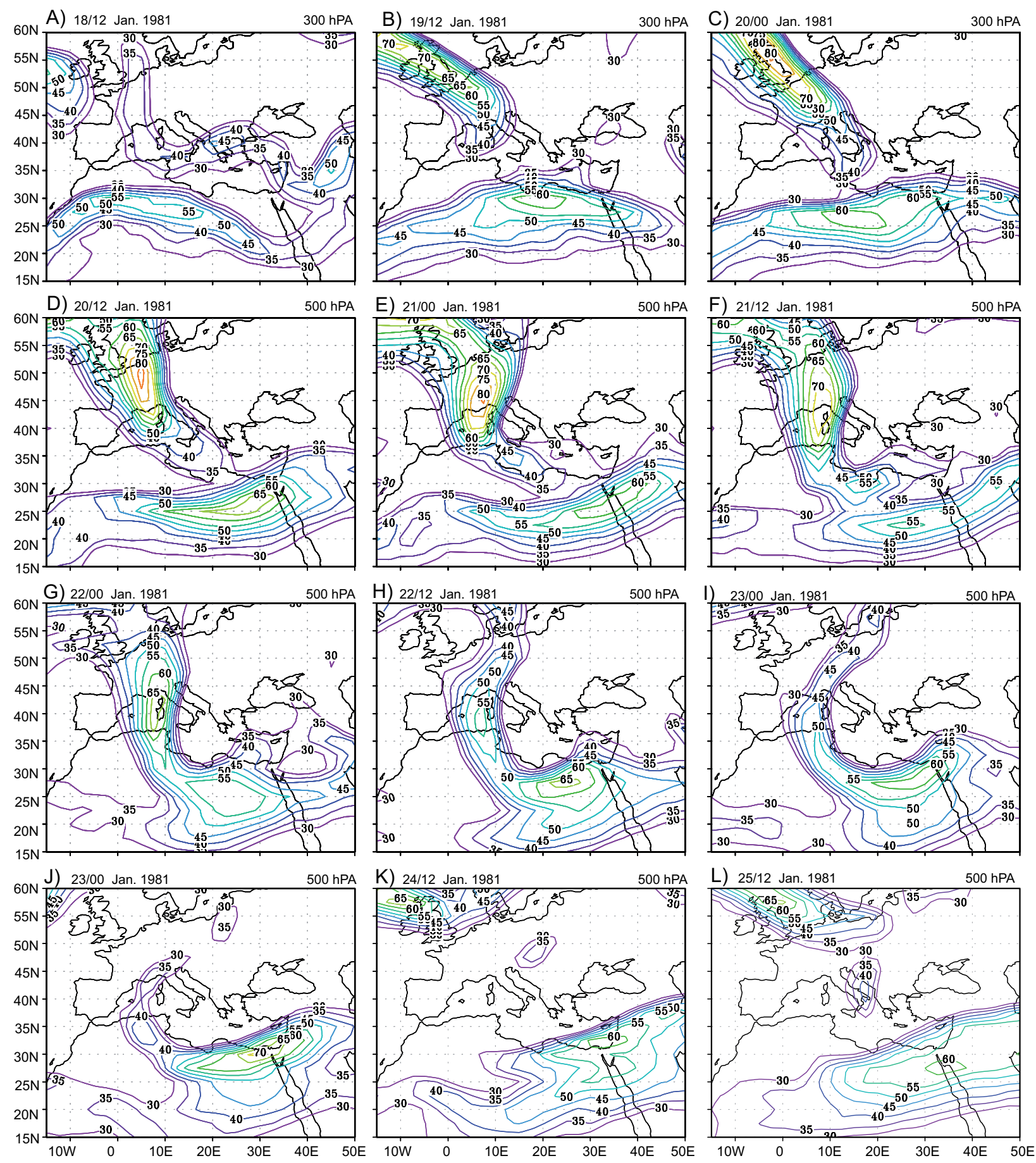

Fig. 3. $300 \mathrm{hPa}$ isotach (wind speed $>30 \mathrm{~m} \mathrm{~s}^{-1}$ ) during the period January 18-25, 1981.

20 at $1200 \mathrm{UTC}$ and above $300 \mathrm{hPa}$ from January 18 at 0000 UTC to January 20 at 0600 UTC. During the growth period (January 20-22) and between the 700$250 \mathrm{hPa}$ layer, the positive values of $T^{\prime} V^{\prime}$ increase up to the maximum from January 20 at 1200 UTC to January 22 at 0600 UTC between $600-250 \mathrm{hPa}$. During the decay period (January 23-25) the values of $T^{\prime} V^{\prime}$ become negative at most levels. Figure $4 \mathrm{~b}$ 
shows that vertically integrated values of $T^{\prime} V^{\prime}$ are positive only during the growth period of the cyclone.

\section{Horizontal distribution of TCO and tropo- pause pressure}

In order to highlight the relation between TCO and tropopause pressure (TP), we present here the horizontal distribution of TCO and TP during the period of study. Figure 5 illustrates the horizontal distribution of the TCO evolution during the period from January 18 to 25 . Figure 5a displays the values of TCO on January 18 at 1200 UTC. It is clear that the higher values of TCO are located over Eastern Europe $\left(45-55^{\circ} \mathrm{N}, 10-30^{\circ} \mathrm{E}\right)$, over the area of the cyclone of interest. According to Figure 5b, within 24 h (January 19 at 1200 UTC) the high values of TCO propagated slightly southeastward associated with the movement of an upper air trough at $500 \mathrm{hPa}$ (Fig. 2b) and its magnitude increased to $450 \mathrm{DU}$. After $24 \mathrm{~h}$ (Fig. 5d) the values of TCO increased (> $450 \mathrm{DU}$ ) and the area of higher values of TCO extended to cover northern Italy and mid-Europe, associated with the formation of a cut-off low at $500 \mathrm{hPa}$ (Fig. $2 \mathrm{~d})$. On January 21 at 1200 UTC, the polar jet associated to the western flank of the upper air trough moved southeastward, where its front reached Algeria, and advected the cut-off low southeastward to reach southern Italy on January 21 at 0000 UTC and northern Libya on January 21 at 1200 UTC. The horizontal distribution of TCO in Figure 5d-g illustrates that the period of maximum development and deepening of the cyclone $\left(T^{\prime} V^{\prime}>0\right)$ is associated with higher values of TCO $(>450 \mathrm{DU})$. This situation continued until January 23 at 0000 UTC, when the main core of higher values of TCO coincided with and associated to the $500 \mathrm{hPa}$ low-pressure center. On January 23 at 1200 UTC (Fig. 5i) the trough had
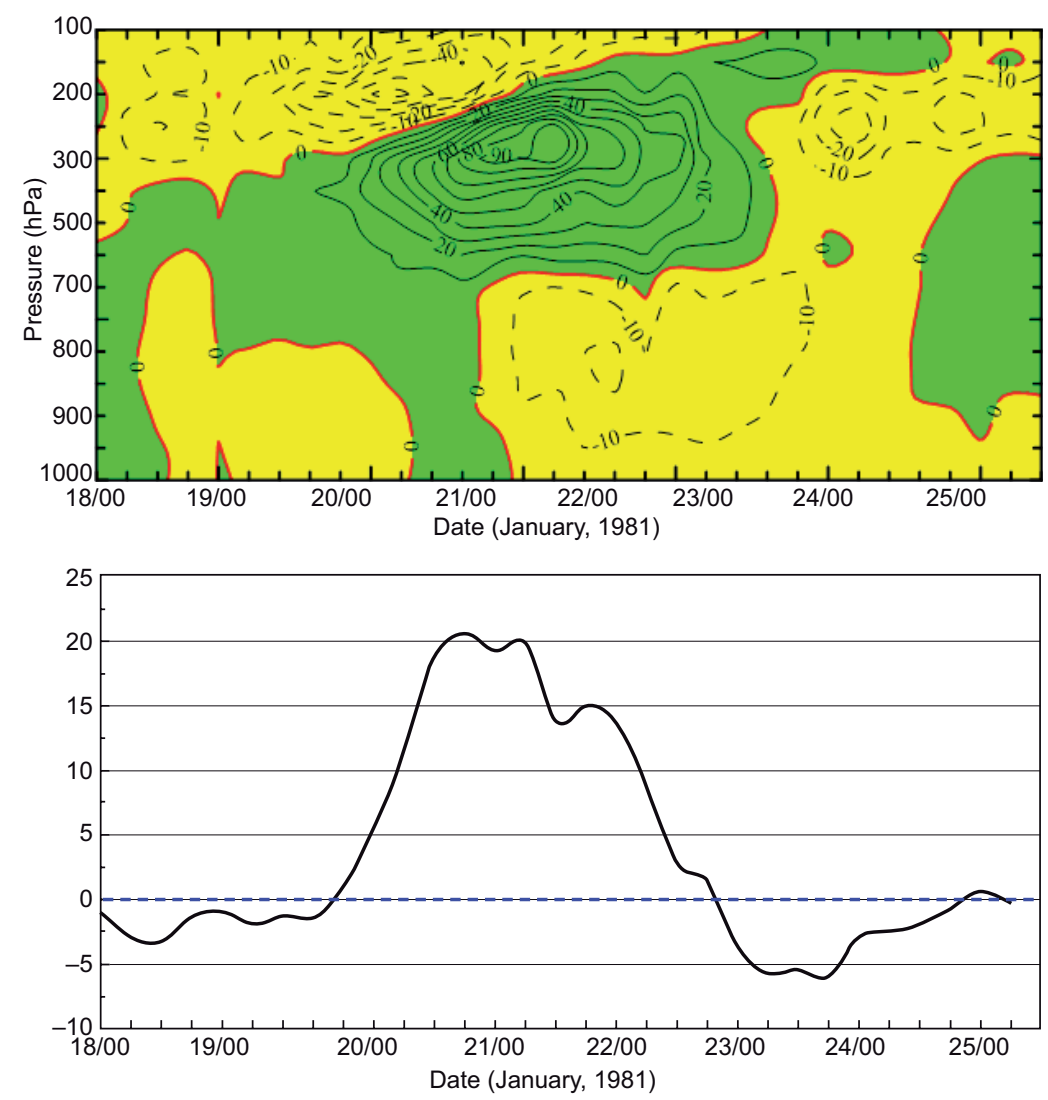

Fig. 4. (a) Time- height variation of $T^{\prime} V^{\prime}$ throughout the life cycle of our cyclone. (b) The area average integrated values of $T^{\prime} V^{\prime}$ throughout the life cycle of our cyclone $\left(T^{\prime} V^{\prime}\right.$ units: $\left.{ }^{\circ} \mathrm{C} \mathrm{m} \mathrm{s}^{-1}\right)$. 
A) $18 / 12$ Jan. 1981
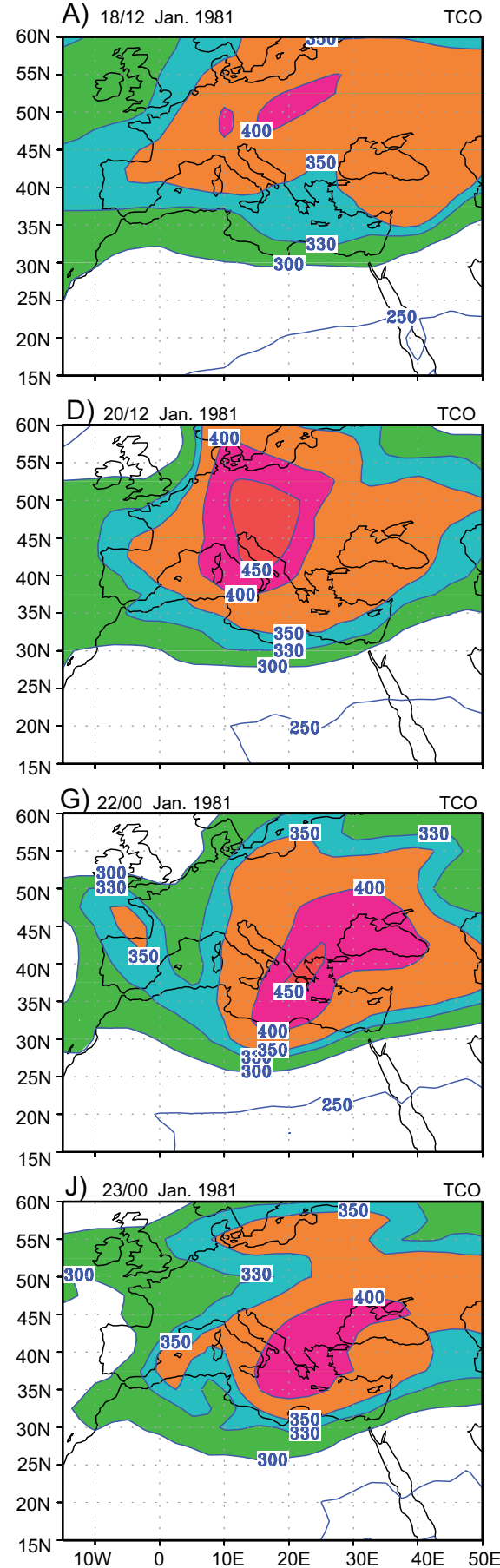

B) 19/12 Jan. 1981

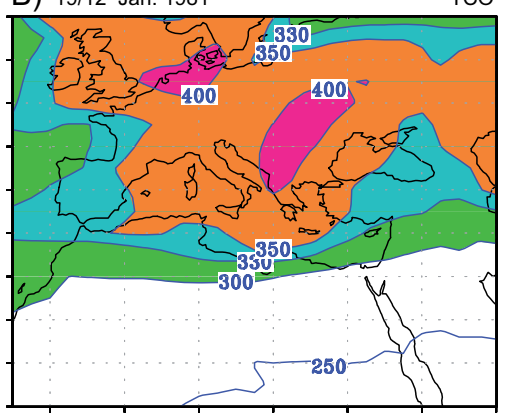

E) $21 / 00$ Jan. 1981
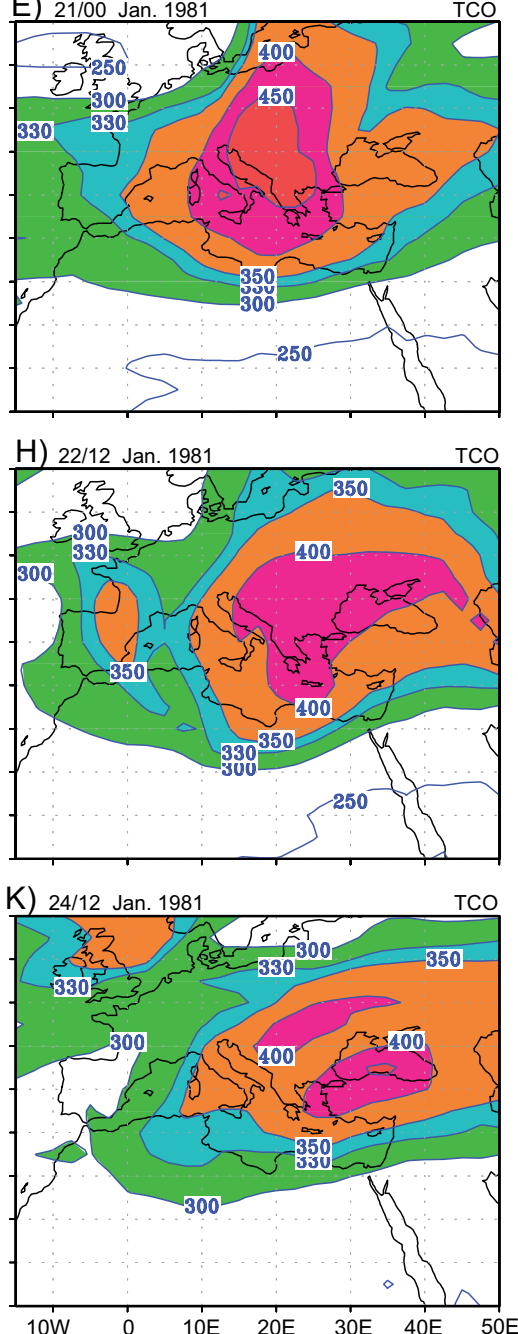

C) 20/00 Jan. 1981
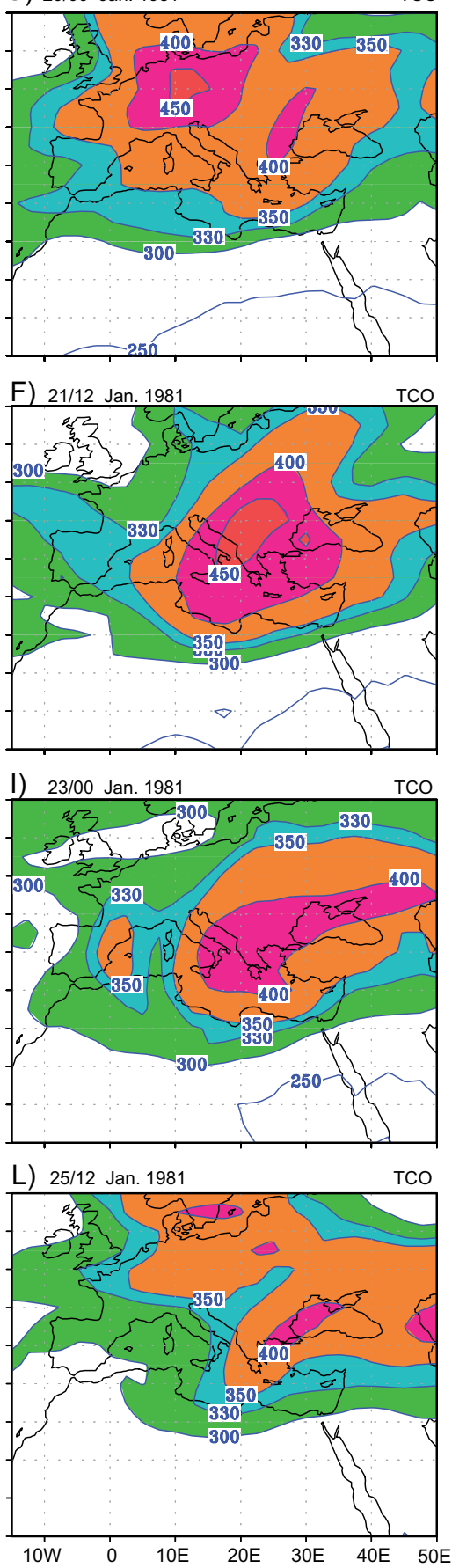

Fig. 5. Horizontal distribution of the vertically integrated values of TCO during the period January 18-25, 1981 (TCO units: DU).

extended horizontally and moved slowly eastward. It is interesting to note that the area of maximum values of TCO decreased in association with the area of low values of geopotential height (center of low at $500 \mathrm{hPa}$ ). On January 24-25, the upper air trough continued eastward latitudinally and its center moved northward (Fig. 5k, 1). It should be noted that the values of TCO decreased. Finally, it can be concluded 
that there is a strong negative relationship between the geopotential height (thickness of the atmosphere), the TCO, and the higher values of TCO that occur during the growth period of the cyclone.

The tropopause is the boundary between the troposphere (a layer of weak stratification) and the stratosphere (a layer of strong stratification) (Holton et al., 1995; Hoinka, 1997, 1998; Highwood and Hoskins, 1998). The global mean height of the tropopause is determined by a balance between the total amount of stratospheric ozone, the surface temperature, and the vertical temperature structure of the troposphere; therefore, changes in any of these values can be expected to lead to changes in the height of the tropopause. The reason for studying the influence of the tropopause pressure on the daily average TCO is that the tropopause forms a boundary surface between comparatively high values of ozone found in the stratosphere and comparatively low values in the troposphere. Figure 6 illustrates the horizontal distribution of the evolution of TP during the period from January 18 to 25 . The comparison between Figures 5 and 6 illustrate that there is a very direct connection between the spatial distribution of ozone and the spatial structure of the tropopause pressure. Two important features from Figure $6 \mathrm{c}$ are that TCO at northern mid-latitudes (during the life cycle of the study cyclone) is highly variable, and that high TCO is strongly related to high tropopause pressure in the previous day and vice versa.

\section{Relationship between ozone and cyclogenesis}

It is known that TCO is linked to synoptic-scale meteorological phenomena. In this section we investigate the relation between total amount of ozone, atmospheric thickness, and tropopause pressure throughout the development of our study case.

\subsection{TCO and thickness correlation}

To investigate the relation between TCO and thickness $(\Delta Z)$, where $\Delta Z$ is the difference between two levels of geopotential height, we divided the troposphere into two layers, the first one between 500 and $1000 \mathrm{hPa}$, and the second one between 100 and 500 $\mathrm{hPa}$. The TCO and the thickness of the two layers $\left(\Delta Z_{1} \sim 500-1000 \mathrm{hPa}, \Delta Z_{2} \sim 100-500 \mathrm{hPa}\right)$ are calculated by averaging all the gridded point values inside the domain that included the cyclone cell throughout the period of study. Figure $7 \mathrm{a}, \mathrm{b}$ illustrates the daily variation in TCO and the values of TCO, $\Delta Z_{1}$ and $\Delta Z_{2}$, where the maximum values of the total amount of ozone and the corresponding minimum values of $\Delta Z_{1}$ and $\Delta Z_{2}$ occurred during the growth period, while the inverse is true during the pre-storm and decay periods. The highest value of TCO during the growth period is about 480 DU on January 21 at 1200 UTC. Finally, it is clear that the relation between the daily values of TCO and the corresponding values of $\Delta Z_{2}$ is robust, while the relation with $\Delta Z_{1}$ is weak. The correlation coefficient ( $\mathrm{r}$ ) between the time series of TCO and the corresponding of $\Delta Z_{1}$ and $\Delta Z_{2}$ during the period of study is 0.292 and -0.748 , respectively. This relationship was used to deduce a linear regression equation relating these parameters.

\subsection{Correlation of TCO and tropopause pressure}

Figure $7 \mathrm{c}$ shows day-to-day variations in the values of TCO and their corresponding tropopause pressure during the period of study. It illustrates a very good correlation between both variables. It is clear that maximum values of the total amount of ozone are associated to maximum values of tropopause pressure and vice versa. It is interesting to note that the maximum values of TCO and maximum values of tropopause pressure occurred during the growth period of the cyclone, from which it can be concluded that when the tropopause descends (i.e., its pressure increases) the fraction of stratospheric air above the location increases, thereby increasing TCO; on the other hand, when the tropopause ascends (i.e., its pressure decreases) there is a corresponding decrease in TCO. The correlation coefficient between TCO and tropopause pressure is 0.289 , which indicates that both values are connected.

\subsection{Semi-empirical formula for estimating ozone from the thickness}

The good correlation coefficients between TCO, thickness $\left(\Delta Z_{1}\right.$ and $\left.\Delta Z_{2}\right)$ and tropopause pressure enables us to establish a linear regression equation relating these parameters, which was made by using the time series (32 values) of TCO, $\Delta Z_{1}, \Delta Z_{2}$ and tropopause pressure represented in Figure 7 . The residual method (Eriksson, 1962) was applied to explore the possibility of forecasting TCO by means of the 

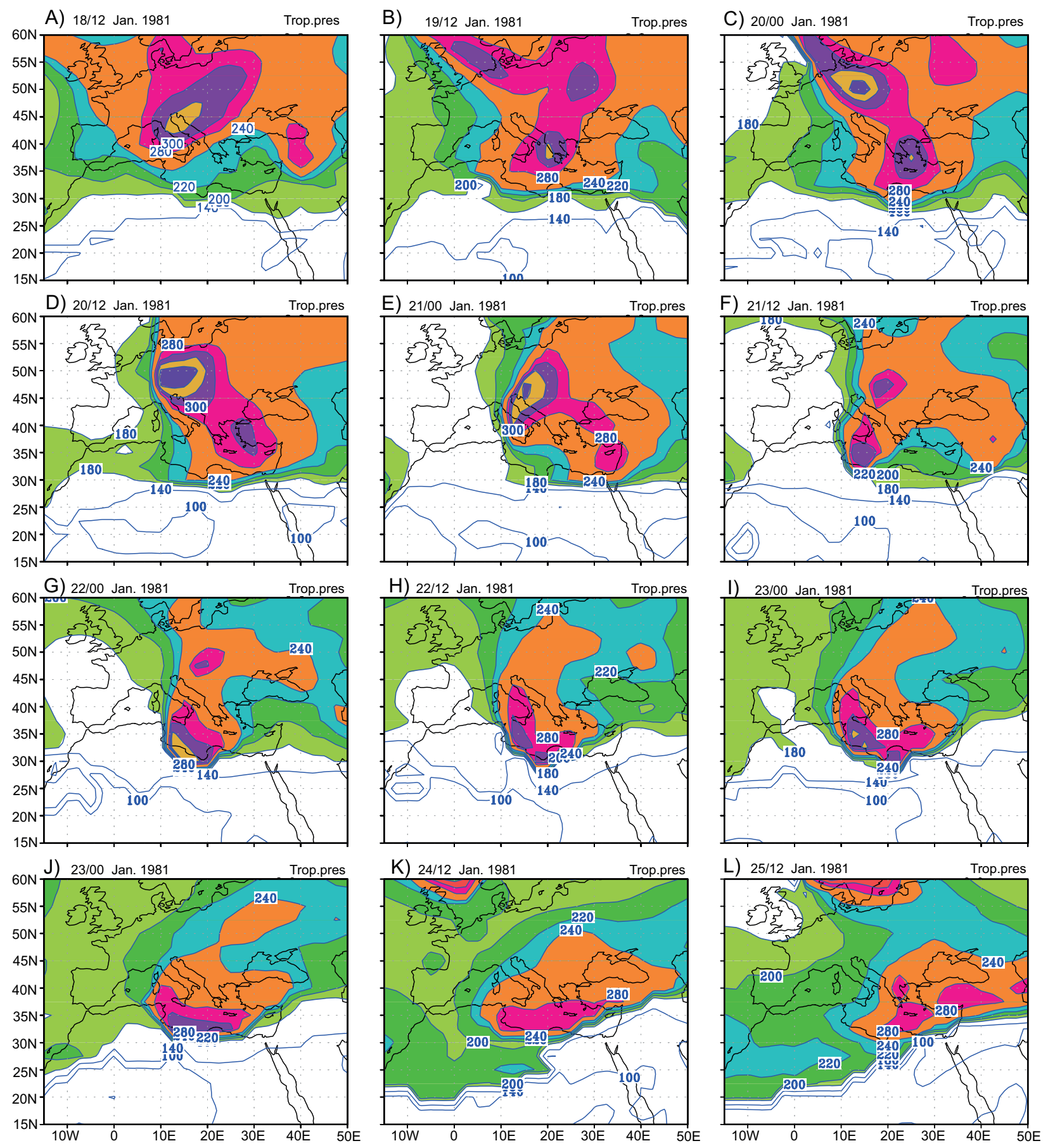

Fig. 6. Horizontal distribution of the tropopause pressure (hPa) during the period January 18-25, 1981.

values of $\Delta Z_{1}$ and $\Delta Z_{2}$ and tropopause pressure. The values of TCO during the period of study (January $18-25,1981)$ were taken as the dependent variable (predictand) and the corresponding values of $\Delta Z_{1}$, $\Delta Z_{2}$ and tropopause pressure were the independent variables (predictors). In the first step, the correlation coefficient $(\mathrm{r})$ between the values of TCO and $\Delta Z_{1}, \Delta Z_{2}$ and tropopause pressure (predictors) is determined. The predictor that has the strongest $r$ with the predictand is used as first predictor, then 

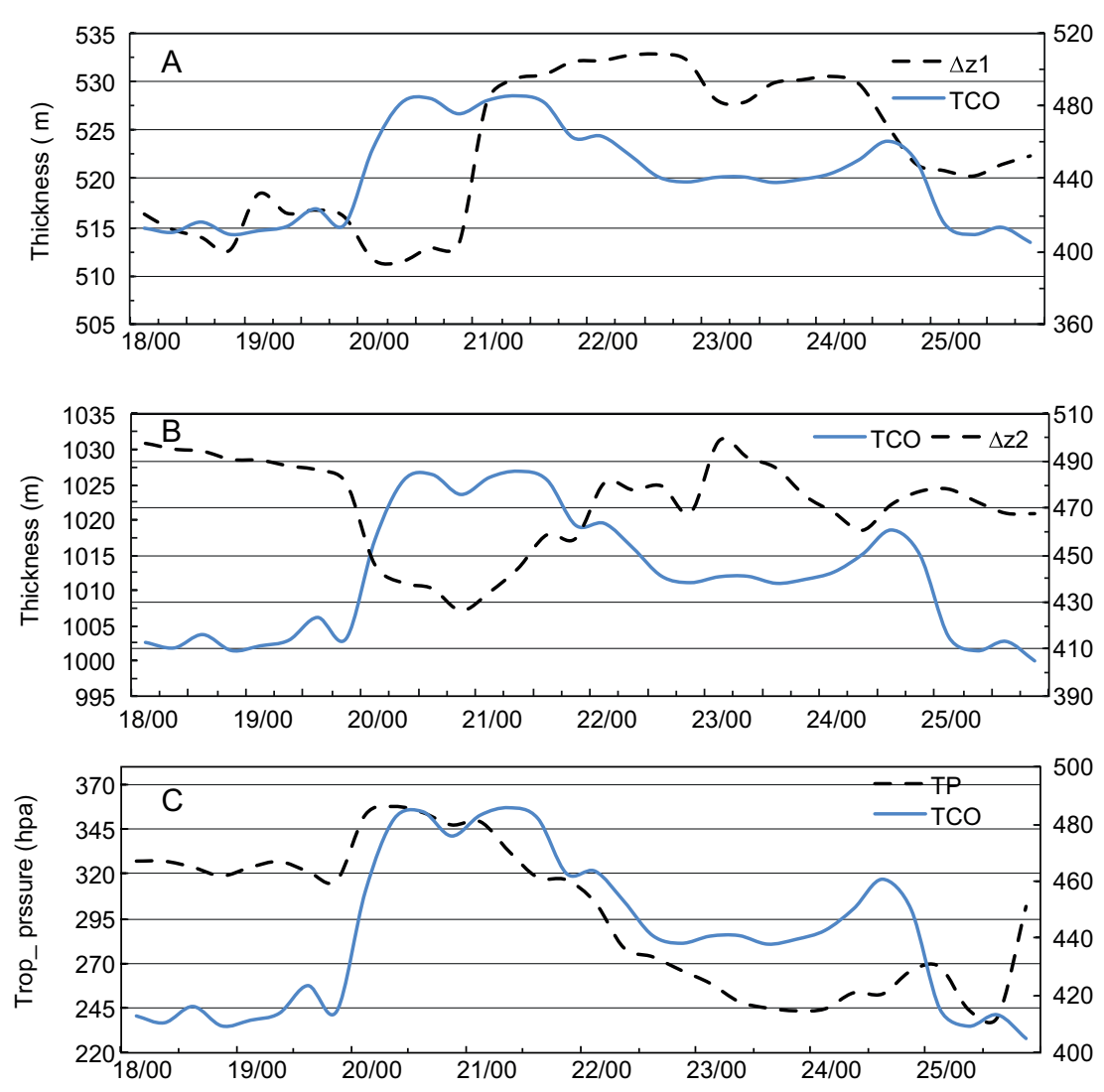

Fig. 7. Average TCO values (DU) during the period January 18-25, 1981. (a) 1000-500 hPa, (b) 500-100 hPa), and (c) tropopause pressure.

the regression line and the regression coefficients are determined. The error between the actual and estimated values of TCO are taken as a predictand. In the second step, the above-mentioned error is subjected to the process performed in the first step. The third step is repeated with new predictors (if there are many predictors) until the additional predictor has no significant effect on the predictand and there is no need for any further steps (i.e., the improvement cannot be expected to be very great with adding new predictors). Table I shows the number of steps, the predictor used in each step, the regression coefficients arising from each step $(A i, B i)$, the root mean square error (RMSE) and mean absolute error (MAE) arising from the error between the actual and estimated data after each

Table I. Regression coefficient $\left(A_{\mathrm{i}}, B_{\mathrm{i}}\right)$, root mean square error, mean absolute error, and multiple correlations (r) from a stepwise regression analysis.

\begin{tabular}{|c|c|c|c|c|c|c|}
\hline \multirow[t]{2}{*}{ Step number } & \multirow[t]{2}{*}{ Predictors } & \multicolumn{2}{|c|}{ Regression coefficients } & \multirow[t]{2}{*}{ RMSE } & \multirow[t]{2}{*}{ MAE } & \multirow[t]{2}{*}{$\mathrm{r}$} \\
\hline & & $A_{\mathrm{i}}$ & $B_{\mathrm{i}}$ & & & \\
\hline 1 & $\mathrm{D} Z_{2}$ & 3465.095 & -2.9581 & 17.193 & 13.914 & 0.75 \\
\hline 2 & $\mathrm{D} Z_{1}$ & -590.519 & 1.1292 & 15.004 & 11.713 & 0.87 \\
\hline 3 & $T P$ & -34.666 & 0.1167 & 10.036 & 8.109 & 0.94 \\
\hline
\end{tabular}


step, and multiple correlation coefficient (r) from a stepwise regression analysis. Table I shows that the total multiple correlations reached 0.94 after using three predictors. This increase in $\mathrm{r}$ is associated to a high decrease in RMSE and MAE. The multiple regression equation for predicting values of TCO from the known preceding values of $\Delta Z_{1}, \Delta Z_{2}$ and tropopause pressure (TP) can be written as follows:

$$
\begin{aligned}
& \mathrm{TCO}=2839.91-2.9581 \times \mathrm{Z} 2+1.1292 \times \mathrm{Z} 1 \\
& \quad+0.1167 \times \mathrm{TP}
\end{aligned}
$$

This equation gives valid values of TCO based on the known thickness of $\Delta Z_{1}$ and $\Delta Z_{2}$ and tropopause pressure, especially in the cases of deep cyclogenesis. The short data record ( 32 values) must temper our results. To obtain more statistically reliable results, long data series (large numbers of cases of cyclogenesis) are required. Figure 8 shows day-to-day variations in the values of observed TCO and its corresponding estimated values arising from Eq. (3).

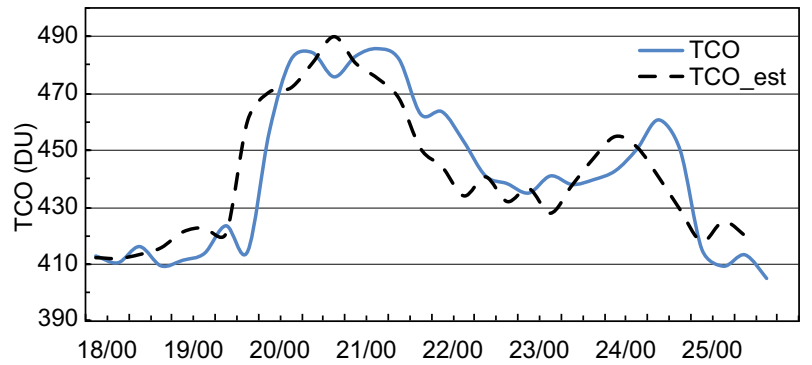

Fig. 8. Values of actual and estimated TCO (DU) for the period January 18-25, 1981.

\section{Vertical variation of ozone}

In this section, the vertical variation of the ozone mixing ratio (OMR) during the study period (January $18-25,1981)$ is analyzed. Therefore, average values of OMR at each level over the domain enclosing the center of the cyclone are determined at each time during the period of study (Fig. 9). Generally, it is clear that higher values of OMR occur between 20-5 hPa levels reaching their maxima between January 19-20. OMR values gradually decrease below and above the layer between 5-20 $\mathrm{hPa}$. The semicircle (red color) found in the 250-350 $\mathrm{hPa}$ layer represents the height of the tropopause at each time of the period of study (Fig. 9). It is clear that during the pre-storm period the height of the tropopause is steady, and there is no variability of OMR above the tropopause, while below the tropopause there is a significant variability in OMR from the surface up to $450 \mathrm{hPa}$. With the beginning of the growth period, the height of the tropopause decreased, especially during the period from January 19 at 1800 UTC to January 21 at 1200 UTC with the maximum decrease January 20 at 1200 UTC, and a sharp change in the vertical gradient of OMR was observed between January 19 at 1800 UTC and January 20 at 0600 UTC in the 100-250 $\mathrm{hPa}$ layer. This high decrease of the tropopause height was associated with the high deepening of the cyclone and was accompanied by a significant vertical increase of OMR in the troposphere and stratosphere. The obvious significant increase of OMR started at the stratospheric layer on January 20 at 0000 UTC and then was transported to the tropospheric layer, where a striking change in

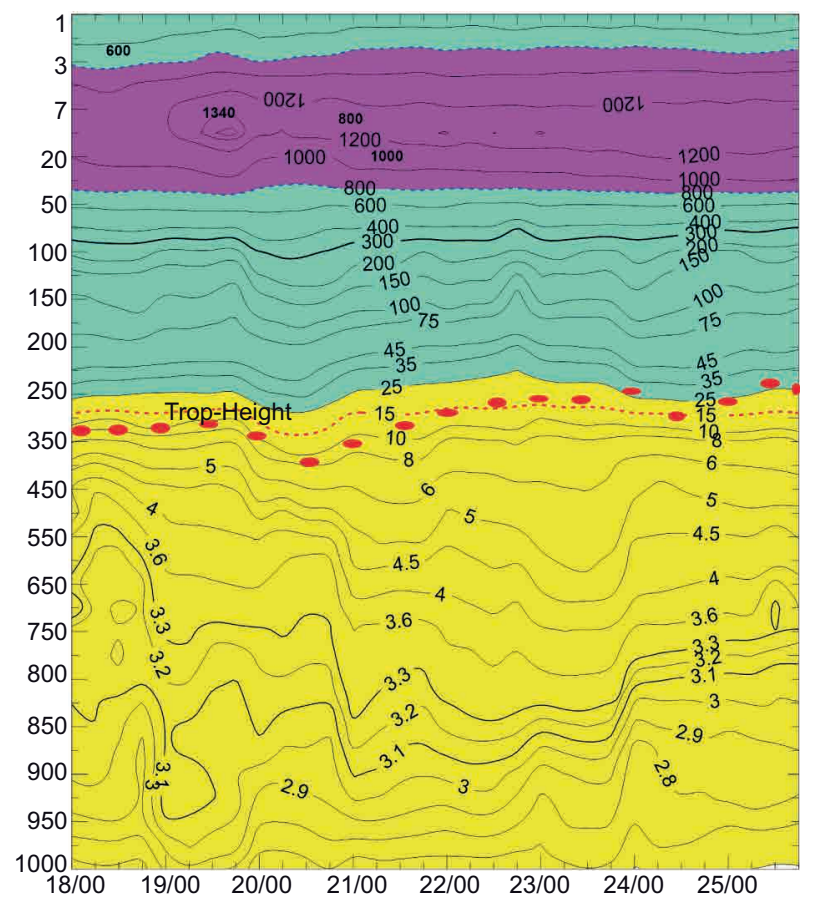

Fig. 9. Vertical profile of OMR (ppm) over the domain containing the center of the cyclone at each level for each time. The semi-circle (red color) in the layer between 400$250 \mathrm{hPa}$ represents the height of the tropopause at each time of the study period. 
the OMR was observed between January 20 at 1800 UTC and January 21 at 0600 UTC below $450 \mathrm{hPa}$. This increase of OMR values below $450 \mathrm{hPa}$ was continuous up to January 23 at 1800 UTC. Figure 9 illustrates also that the height of the tropopause increased and the values of OMR decreased gradually in the troposphere from the beginning of the decay (January 23 at 1900 UTC) to the end of study period. A sharp change in the vertical gradient of OMR between January 23 at 1200 UTC and January 24 at 0600 UTCvbelow $650 \mathrm{hPa}$ was also noticed. After 24/06 and up to the end of the study period January 25 at 1800 UTC an obvious decrease in OMR occured from the surface to $100 \mathrm{hPa}$, where the greater variability in OMR values obviously occurs, especially in the period of peak cyclonic development.

Figure 10a illustrates the time-height variation of the differences of OMR between the average of the domain containing the center of the cyclone at each level and the corresponding monthly average during the period from January 13 to 25 . Figure 10a shows that negative values of OMR differences appear above $700 \mathrm{hPa}$ up to the end of the atmosphere during the period from January 13 to 15 . The lower level of the negative values raised to $700 \mathrm{hPa}$ on January 18. The higher negative values occurred between the 400 and $10 \mathrm{hPa}$ levels. With the beginning of the cyclone formation and development on January 18, the positive values of the OMR difference appeared
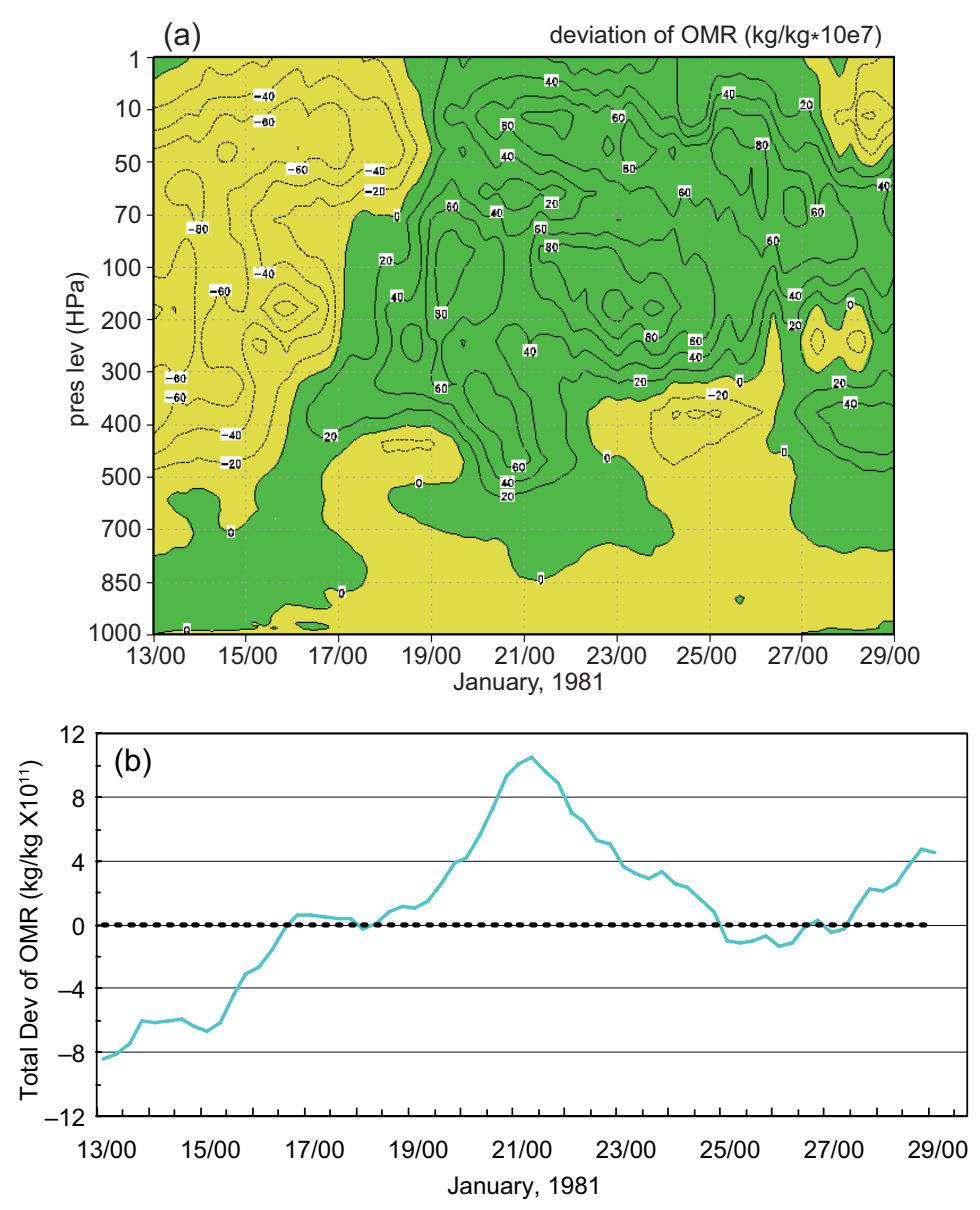

Fig. 10. (a) Time-height variation of the differences of OMR between the average of the domain containing the center of the cyclone at on January 21 at 1200 UTC and the corresponding monthly average. (b) Total vertical average values of OMR differences. 
above the $400 \mathrm{hPa}$ level on January 19-20. These values increased with height to reach their maxima between 700 and $300 \mathrm{hPa}$. During the days of maximum deepening and cyclogenesis (January 20-23), the positive values extended downward to reach the $850 \mathrm{hPa}$ level. The increase in positive values continued to be higher in the upper levels to reach maximum values between $300-100 \mathrm{hPa}$ and also between $60-10 \mathrm{hPa}$. The characteristics of these changes of OMR concentrations from layer to layer are predominantly due to dynamical processes; also, they were attributed to the effect of horizontal advection of ozone from a neighboring region into the column, and by a vertical exchange of air between the high ozone in the stratosphere and the low ozone in trhe troposphere. There is a number of mechanisms to account for the stratosphere-troposphere exchange of ozone, which were discussed by Wei (1986). It is clear that in this case there is a transport of air mass from the lower stratosphere (rich in ozone) to the upper troposphere (stratosphere-troposphere exchange), through which a significant amount of stratospheric ozone penetrates into the troposphere (Levy et al., 1980).

Figure $10 \mathrm{~b}$ shows the vertical average values of the differences of OMR between the averages of the domain containing the center of the cyclone at each level and the corresponding monthly average for the period from January 13 to 29 . The figure illustrates that there is a decrease of OMR from the monthly average during the period from January 13 at 0000 UTC to January 16 at 1200 UTC. With the beginning of the formation of the cyclone the difference between the daily values of OMR from the corresponding monthly average becomes positive and increases gradually to reach its maximum values on January 20-22, associated to the maximum deepening of the cyclone. The comparison between Figures $10 \mathrm{~b}$ and $4 \mathrm{~b}$ illustrates that the negative and positive values of the OMR difference are associated with $T^{\prime} V^{\prime}<0$ and $T^{\prime} V^{\prime}>0$, respectively, which means that the values of ozone increase with the formation and development of the cyclone.

\section{Summary and conclusions}

The relation between TCO and the development of a cyclonic system that occurred in the period January
$18-25,1981$, has been studied. It was found that during the pre-storm period the area average integrated values of $T^{\prime} V^{\prime}$ are negative, associated to lower values of TCO, while with the beginning of the growth period (January 20-22) the area average integrated values of $T^{\prime} V^{\prime}$ are positive, associated to higher values of TCO. During the decay period, the area average integrated values of $T^{\prime} V$ ' become negative and are associated to lower values of TCO. This illustrates that there is a strong relationship between the cyclogenesis and development of the case study and the values of TCO.

The relation between TCO and the thickness between $1000-500 \mathrm{hPa}, 500-100 \mathrm{hPa}$ and the tropopause pressure has been investigated during the period of cyclone development (January 18-25, 1981). A strong correlation was found between TCO and the above-mentioned parameters, especially during the periods of maximum development of a cyclonic system. The residual method has been used to derive a linear regression equation that relates TCO with the thickness and tropopause pressure. This equation was deduced from the short data record of 32 values representing the period of study and must be taken as preliminary, subject to further detailed examination. To obtain more statistically reliable results, long data series (large numbers of cases of cyclogenesis) are required.

The daily variations of TCO based on the vertical distribution of OMR (37 levels) have been studied throughout the period of interest. It was noted that during the pre-storm period there were no vertical changes in OMR values above the tropopause, while below the tropopause a small vertical changes in OMR values occurs from the surface up to $350 \mathrm{hPa}$. With the beginning of the growth period, the height of the tropopause decreased, especially during the period from January 19 at 1800 UTC to January 21 at 1200 UTC, with a maximum decrease on January 20 at 1200 UTC. This high decrease of the tropopause height, which was associated to high deepening of the cyclone, was accompanied by a significant vertical increase of OMR in the troposphere and stratosphere. The obvious significant increase of OMR started at the stratospheric layer on January 20 at 0000 UTC and was then transported to the tropospheric layer, persisting throughout the period from January 21 at 0000 UTC to January 
23 at 1800 UTC. With the beginning of the decay period (January 23 at 1900 UTC), the height of the tropopause increased and the values of OMR decreased gradually in the troposphere until end of study period. Obviously, the greater variability in OMR values occured in the layer from the surface to $100 \mathrm{hPa}$, especially during the peak of the cyclone development. The analysis of the time-height variation of the differences of OMR between the average of the domain containing the center of the cyclone at each level and the corresponding monthly average illustrates that during the days of maximum deepening and cyclogenesis the positive values of OMR extended downward to reach the $850 \mathrm{hPa}$ level. This means that there is a transport of air mass from the lower stratosphere (rich in ozone) to the upper troposphere (stratosphere-troposphere exchange), through which a significant amount of stratospheric ozone penetrates into the troposphere.

\section{References}

Abdel Basset H, Gahein A. 2003. Diagnostic study on the relation between ozone and potential vorticity. Atmósfera 16:67-82.

Buzzi A, Tibaldi S. 1978. Cyclogenesis in the lee of Alps: A case study. Quarterly Journal of the Royal Meteorological Society 104:271-287.

DOI: 10.1002/qj.49710444004

Dee DP, Uppala SM, Simmons AJ, Berrisford P, Poli P, Kobayashi S, Andrae U, Balmaseda MA, Balsamo G, Bauer P, Bechtold P, Beljaars AC, van de Berg L, Bidlot J, Bormann N, Delsol C, Dragani R, Fuentes M, Geer AJ, Haimberger L, Healy SB, Hersbach H, Hólm EV, Isaksen L, Kållberg P, Köhler M, Matricardi M, McNally AP, Monge-Sanz BM, Morcrette J, Park B, Peubey C, de Rosnay P, Tavolato C, Thépaut J, Vitart F. 2011. The ERA-Interim reanalysis: Configuration and performance of the data assimilation system. Quarterly Journal of the Royal Meteorological Society 137:553597. DOI: $10.1002 /$ qj. 828

Defant F, Taba H. 1957. The threefold structure of the atmosphere and the characteristics of the tropopause. Tellus 9:259-275.

DOI: $10.3402 /$ tellusa.v9i3.9112

Derwent R, Jenkin M, Saunders S, and Pilling M. 1998. Photochemical ozone creation potentials for organic compounds in northwest Europe calculated with a master chemical mechanism. Atmospheric Environment 32:2429-2441.

DOI: 10.1016/j.atmosenv.2017.05.024

Dobson G. M. B., 1973. The laminated structure of the ozone in the atmosphere. Quarterly Journal of the Royal Meteorological Society 99:599-607.

DOI: 10.1002/qj.49709942202

Dobson GMB. 1931. A photoelectric spectrometer for measuring the amount of atmospheric ozone. Proceedings of the Physical Society 43:324-339.

Dobson GMB, Brewer AW, Cwilong BM. 1946. Bakerian lecture. Meteorology of the lower atmosphere. Proceedings of the Royal Society of London Series A 185:144-175.

DOI: $10.1098 /$ rspa.1946.0010

Dobson GMB, Harrison DN. 1926. Measurement of the amount of ozone in the Earth's atmosphere and its relation to other geophysical conditions. Proceedings of the Royal Society of London Series A 110:660-693. DOI: 10.1098/rspa.1926.0040

Dobson GMB, Harrison DN, Lawrence J, 1929. Measurements of the amount of ozone in the Earth's atmosphere and its relation to other geophysical conditions. Part III. Proceedings of the Royal Society of London Series A 122, 456-486.

DOI: $10.1098 /$ rspa.1929.0034

Dütch HU. 1978. Vertical ozone distribution on a global scale. Pure and Applied Geophysics 116:511-529. DOI: 10.1007/BF01636904

Eisele H, Scheel HE, Sladkovic R, Trickl T. 1999. High-resolution LIDAR measurements of stratosphere-troposphere exchange. Journal of Atmospheric Sciences 56:319-330. DOI: 10.1175/1520-0469(1999)056<0319:HRLMOS $>2.0 . \mathrm{CO} ; 2$

Eriksson B. 1962. Statistical analysis and prognosis in meteorology. Part 3. Simple method for statistical prognoses. Technical Note. No. 71. World Meteorological Organization.

Gomis D, Buzzi A, Alonso S. 1990. Diagnosis of mesoscale structures in cases of lee cyclogenesis during ALPEX. Meteorology and Atmospheric Physics 43:4957. DOI: $10.1007 / \mathrm{BF} 01028108$

Highwood EJ, Hoskins BJ. 1998. The tropical tropopause. Quarterly Journal of the Royal Meteorological Society 124:1579-1604. DOI: 10.1002/qj.49712454911

Hoinka KP. 1997. The tropopause: discovery, definition and demarcation. Meteorologische Zeitschrift 6:281303. DOI: $10.1127 / \mathrm{metz} / 6 / 1997 / 281$ 
Hoinka KP. 1998. Statistics of the global tropopause pressure. Monthly Weather Review 126:3303-3325. DOI: 10.1175/1520-0493(1998)126<3303:SOTGT$\mathrm{P}>2.0 . \mathrm{CO} ; 2$

Holton JR. 1972. An introduction to dynamic meteorology. 1st ed. Academic Press, 391 pp.

Holton JR, Haynes PH, Douglass AR, Rood RB, Pfister L. 1995. Stratosphere-troposphere exchange. Revues of Geophysics 33:403-439. DOI: 10.1029/95RG02097

Homar V, Jansa A, Campins J, Genoves A, Ramis C. 2007. Towards a systematic climatology of sensitivities of Mediterranean high impact weather: A contribution based on intense cyclones. Natural Hazards and Earth System Sciences 7:445-454.

DOI: 10.5194/nhess-7-445-2007

Itoh H, Narazaki Y. 2016. Fast descent routes from within or near the stratosphere to the surface at Fukuoka, Japan, studied using 7Be measurements and trajectory calculations, Atmospheric Chemistry and Physics 16:6241-6261. DOI: 10.5194/acp-16-6241-2016

Karacostas TS, Flocas AA. 1983. The development of the "bomb" over the Mediterranean area. Conference sur le Climat Mediterraneen et les Resources en Eau, Marseille, France, August 6. Société Météorologique de France.

Keyser D, Shapiro MA. 1986. A review of the structure and dynamics of upper-level frontal zones. Monthly Weather Review 114, 452- 499.

DOI: $10.1175 / 1520-0493(1986) 114<0452$ :AROT$\mathrm{SA}>2.0 . \mathrm{CO} ; 2$

Kouroutzoglou J, Flocas HA, Keay K, Simmonds I, Hatzaki M. 2013. A high-resolution climatological study on the comparison between surface explosive and ordinary cyclones in the Mediterranean. Regional Environmental Change 14:1833-1846. DOI: 10.1007/ s10113-013-0461-3

Kouroutzoglou J, Flocas HA, Simmonds I, Keay K, Hatzaki M. 2011. Climatological aspects of explosive cyclones in the Mediterranean. International Journal of Climatology a 31:1785-1802. DOI: 10.1002/joc.2203

Krishnamurti TN. 1961. The subtropical jet stream of winter. Journal of Meteorology 18:172-191.

DOI: $10.1175 / 1520-0469(1961) 018<0172$ :TSJSOW $>2.0 . \mathrm{CO} ; 2$

Kuang S, Newchurch MJ, Johnson MS, Wang L, Burris J, Pierce RB, Feng N. 2017. Summertime tropospheric ozone enhancement associated with a cold front passage due to stratosphere-to-troposphere transport and biomass burning: Simultaneous ground-based lidar and airborne measurements. Journal of Geophysical Research: Atmospheres 122:1293-1311.

DOI: 10.1002/2016JD026078

Langford AO, Brioude J, Cooper OR, Senff CJ, Alvarez RJ, Hardesty RM, Oltmans SJ. 2012. Stratospheric influence on surface ozone in the Los Angeles area during late spring and early summer of 2010. Journal of Geophysical Research 117:D00V06.

DOI: 10.1029/2011JD016766.

Langford AO, Alvarez RJ, BrioudeII J, Fine R, Gustin MS, Lin MY, Marchbanks RD, Pierce RB, Sandberg SP, Senff CJ, Weickmann AM, Williams EJ. 2017. Entrainment of stratospheric air and Asian pollution by the convective boundary layer in the southwestern U.S. Journal of Geophysical Research: Atmospheres 122:1312-1337.

DOI: 0.1002/2016JD025987

Langford A, Senff CJ, Alvarez RJ, Brioude J, Cooper O, Holloway J, Williams E. 2015. An overview of the 2013 Las Vegas Ozone Study (LVOS): Impact of stratospheric intrusions and long-range transport on surface air quality. Atmospheric Environment 109:305-322. DOI: 10.1016/j.atmosenv.2014.08.040

Langford B, Davison B, Nemitz E, Hewitt CN. 2009. Mixing ratios and eddy covariance flux measurements of volatile organic compounds from an urban canopy (Manchester, UK), Atmospheric Chemistry and Physics 9:1971-1987. DOI: 10.5194/acp-9-1971-2009

Levy H, Mahlman JD, Moxim WJ. 1980. Stratospheric NO. A major source of reactive nitrogen in the unpolluted troposphere. Geophysical Research Letters 7:441-444. DOI: 10.1029/GL007i006p00441

Lionello P, Bhend J, Buzzi A., Della-Marta PM, Krichak SO, Jansa A, Maheras P, Sanna A, Trigo IF, Trigo R. 2006. Cyclones in the Mediterranean region: Climatology and effects on the environment. Developments in Earth and Environmental Sciences 4:325-372.

DOI: $10.1016 / \mathrm{S} 1571-9197(06) 80009-1$

Loewe F, Radok V. 1950. A meridional aerological cross section in the southwest Pacific. Journal of Meteorology 7, 5865. DOI: 10.1175/1520-0469(1950)007<0058:AMAC$\mathrm{SI}>2.0 . \mathrm{CO} ; 2$

Mohri K. 1953. On the fields of wind and temperature over Japan and adjacent waters during winter of 1950-1951. Tellus 5A:340-358. DOI: 10.3402/tellusa.v5i3.8582

Namias J, Clapp PF. 1949. Confluence theory of the high tropospheric jet stream. J. Meteor., 6, 330-336. 
Newton, C W. 1954. Frontogenesis and frontolysis as a three-dimensional process. Journal of Meteorology 11:449-461. DOI: 10.1175/1520-0469(1954) $011<0449$ :FAFAAT $>2.0 . \mathrm{CO} ; 2$

Ott LE, Duncan BN, Thompson AM, Diskin G, Fasnacht Z, Langford AO, Yoshida Y. 2016. Frequency and impact of summertime stratospheric intrusions over Maryland during DISCOVER-AQ (2011): New evidence from NASA's GEOS-5 simulations. Journal of Geophysical Research 121:3687-3706.

DOI: 10.1002/2015JD024052

Palmén E, Newton CW. 1969. Atmospheric circulation systems. Their structure and physical interpretation. Academic Press, 603 pp.

Reed RJ. 1950. The role of vertical motions in ozone-weather relationships. Journal of Meteorology 7:263-267. DOI: $10.1175 / 1520-0469(1950) 007<0263$ :TRO$\mathrm{VMI}>2.0 . \mathrm{CO} ; 2$

Reiter ER, Gao DY. 1982. Heating of the Tibet Plateau and movements of the South Asian high during spring. Monthly Weather Review 110:1694-1711.

DOI: 10.1175/1520-0493(1982)110<1694:HO TTPA $>2.0 . \mathrm{CO} ; 2$

Riehl H. 1962. Jet streams of the atmosphere. Technical report 32. Colorado State University, Department of Atmospheric Science, 117 pp.

Shapiro MA, Keyser D. 1990. Fronts, jet streams and the tropopause. In: Extratropical Cyclones. The Erik Palmén memorial volume (Newton C, Holopainen EO, Eds.). American Meteorological Society, Boston, MA, 167-191.

DOI: 10.1007/978-1-944970-33-8_10

Shapiro MA, Krueger AJ, Kennedy PJ. 1982. Nowcasting the position and intensity of jet streams using a sateliteborne Total amount of ozone Mapping Spectrometer, in Nowcasting ed. K. A. Browning. Academic Press, London.

Škerlak B, Sprenger M, Wernli H. 2014. A global climatology of stratosphere-troposphere exchange using the ERA-Interim data set from 1979 to 2011. Atmospheric Chemistry and Physics 14:913-937.

DOI: $10.5194 / \mathrm{acp}-14-913-2014$
Stohl A, Haimberger L, Scheele MP, Wernli H. 2001. An inter-comparison of results from three trajectory models. Meteorological Applications 8:27-135.

DOI: $10.1017 / \mathrm{S} 1350482701002018$

Sutcliffe RC, Bannon J K. 1954. Seasonal changes in the upper-air conditions in the Mediterranean-Middle East area. Proceedings of the International Association of Meteorology (UGGI), Rome, Italy, 322-334.

Thompson AM, Pickering KE, Dickerson RR, Ellis WG, Jacob DJ, Scala JR, Tao WK, McNamara DP, Simpson J. 1994. Convective transport over the central United States and its role in regional CO and ozone budgets. Journal of Geophysical Research 99 (D9): 18703-18711.

DOI: 10.1029/94JD01244

Uccellini LW, Keyser D, Brill KF, Wash CH. 1985. The Presidents' Day cyclone of 18-19 February 1979: Influence of upstream trough amplification and associated tropopause folding on rapid cyclogenesis. Monthly Weather Review 113:962-988.

DOI: $10.1175 / 1520-0493(1985) 113<0962$ :TPD$\mathrm{COF}>2.0 . \mathrm{CO} ; 2$

Vaughan G, Price JD. 1989. Ozone transport into the troposphere in cutoff low event. In: Ozone in the atmosphere. Proceedings of the Quadrennial Ozon Symposium 1988 (Bojkov RD, Fabian P, Eds.). Hampton, Virginia, 415-418.

Viezee W, Johnson WB, Singh HB. 1983. Stratospheric ozone in the lower troposphere. II. Assessment of downward flux and ground-level impact. Atmospheric Environment 17, 1979-1993.

DOI: 10.1016/0004-6981(83)90354-2

Wei MY. 1986. A formulation of the stratosphere-troposphere exchange processes an objective determination of the tropopause level. Second International Conference on Southern Hemisphere Meteorology, December 1-5. American Meteorological Society, Wellington, New Zealand, 320-323.

WMO. 1986. Atmospheric ozone, 1985. Global Ozone research and Monitoring Report. Report No. 16. World Meteorological Organization, 392 pp. 